\title{
PROBLEM LOAN IDENTIFICATION \\ AND MANAGEMENT (PLIM) SYSTEM
}

\author{
Bart P. Hartman \\ and Vincent $C$. Brenner
}

Department of Accounting

Louisiana State University

Baton Rouge, Louisiana

Reed F. Bilbray

American Bank and Trust Company

Baton Rouge, Louisiana

Gradual deregulation has increased the pressure on financial institutions to produce profits once easily obtained in the protected banking industry. The recent economic recession highlighted this pressure as keener competition became necessary for survival. When interest rates on deposited funds soared and loan demand softened, institutions assumed more risk to remain profitable. As a result, financial institutions loaned money to countries, companies, or individuals that were more risky than normal. The effects of such a policy are evident in both the sizable loan losses being reported and in the number of banks facing financial difficulties. Institutions are discovering that these higher risk loans are contributing to losses that often negate the profits such loans provide.

Loan losses are often a result of the institutions' poor procedures for problem loan identification and management. The ability of an institution to recognize when a loan is experiencing difficulty is increasingly important in minimizing loan losses. This paper examines a Problem Loan Identification and Management (PLIM) System useful for quickly identifying potential problem loans in an institution's portfolio and techniques to manage them efficiently. The information presented was gather in part through interviews and from guidelines of two well-established mid-sized commercial banks in the Southwest. A case history of a problem loan was provided by one of the banks and is used to illustrate the methods of identifying and managing a problem loan. 


\section{Identifying Problem Loans}

Various items can provide an early warning of potential problem loans. Exhibit A sets forth ten early warning signals.

\section{EXHIBIT A}

\section{Early Warning Signals For Problem Loans}

1. Borrower's deteriorating financial statements

2. Loan payments past due

3. Borrower experiencing account overdirafts

4. Loans are renewed without reduction in principal

5. Borrower is experiencing personal financial problems

6. Significant decreases in borrower's average account balances

7. Borrower is experiencing foreclosures, civil suit judgments, etc.

8. Inquiries received from other lending institutions regarding borrower

9. Borrower's failure to file requested information, particularly financial data

10. Borrower seeks extension of loan term

The PLIM system for identification and detection of potential or actual problem loans consists of several methods which are designed to produce signals, any or all of which could quickly indicate the necessity to begin further investigation. The methods include: (1) portfolio and financial statement analysis, (2) past due reports, (3) overdraft listings, financial institution inquiries, and checking account variability, (4) outside sources of information, (5) renewed loans without principal reductions, and (6) other unusual factors. The loan review department working with the responsible loan officer should use these methods to manage the bank's loan portfolio.

\section{Portfolio and Financial Statement Analysis}

Each quarter, the bank's loan portfolio is analyzed by the Loan Review Department. The analysis usually takes a top-down approach which begins with an overall portfolio analysis. This analysis is similar to an evaluation of which securities to include in a stock portfolio. For example, some banks have a policy of maintaining one-third of its loan portfolio in each of three specific loan areas - real estate, commercial, and consumer. Such a policy is aimed at spreading the bank's risk so as to minimize the effect of a drastic downturn in one of the areas. The portfolio analysis is used to review the mix of outstanding loans to determine if bank policy is being followed and to assess current risk exposure.

After the portfolio mix by type of loan is reviewed, the mix within each of these portfolios should be reviewed. For example, in the commercial loan area, a review should be made to determine the mix of industries, type of 
loan collateral etc. There should not be an over emphasis on one industry because if the industry falls upon hard times the bank could experience significant losses. The goal again is to spread the risk.

The overall portfolio review is followed by a review of each individual loan officer's portfolio. The officer's entire portfolio is reviewed because frequently the loan follows patterns that reflect management ability and/or economic exposure. A lengthy list of exceptions is a strong indication of documentation problems and immediate corrective actions should be instituted to limit the bank's exposure on the loans. Loan officers typically specialize in a particular industry or region resulting in the concentrated portfolio mirroring the respective economic trend. A track record should be maintained for each loan officer in terms of adequacy of documentation, etc. as well as his history of loan profits to losses. Such a record can be used in employee evaluations as well as for pinpointing individuals who are very successful or who may need additional training or increased supervision.

To complete the top-down approach, the company itself is analyzed. When annual financial statements of the company are received, ratios are calculated and horizontal and vertical analysis are performed. Today this analysis is frequently done using a micro computer and spreadsheet software. To assist in the financial statement analysis, Robert Morris and Associates annual studies are used for industry average data for various businesses. The payment history is also reviewed to determine the current status of the account. The result of this compilation of data is reviewed by the loan officer and loan review officer to settle any discrepancies or questions and to correct any problems that may exist.

\section{Past Due Report}

In most banks a past due report is issued at regular intervals and is contrasted with the loan officer's portfolio analysis. Since timeliness is essential, the past due reports should be prepared weekly. This report is frequently the first indicator of a specific problem loan. The loan review officer should meet at regular intervals with the loan officers to discuss their past due accounts. Again, because of the important of timeliness, this meeting should be on a weekly or biweekly basis. The bank should set a policy concerning when an account is considered past due. The length of time should be sufficiently long to eliminate the detailed review of loans where payment may have been delayed by mail or by other nonsignificant delays. A period of 15 to 20 days after the due date is recommended for considering a loan past due. Banks should establish a particular past due date when the loan receives special or detailed treatment or analysis. For example, once a loan reaches 90 days past due it should be immediately placed in the hands of a special loan officer and several actions instituted such as accounting status, collateral valuation and risk classification. 


\section{Overdraft Lists, Financial Institution Inquiries, and Checking Accounts}

These three indicators alert either the loan officer or loan review officer of potential managment, sales, or cash flow problems in a company. Frequent appearance on the daily overdraft list should indicate that the company does not have enough cash to support operations and could result in late or missed payments on the outstanding loans. Frequent overdrafts may also indicate that the borrower does not have an adequate accounting staff. If this is the case, the bank may suggest that the client obtain the necessary accounting services so that he can more efficiently operate his business.

Any inquiry from another bank or financial institution on the company should be studied as well. Frequently such inquiries mean that the client may be seeking to borrow additional funds. While a new loan may satisfy a short-term need of cash for the company or expand their production capacity, the overall risk or exposure of the institutions involved may be increased because of the long-term inability of the company to raise cash from its operations to service the increasing debt. Sometimes a company's checking account can also signal potential problems. For example, if sudden changes in account balances from historically high levels to low or insignificant amounts occur, this could indicate funds mismanagement, a sales decline, or rapid operating expenses increases, any of which might cause future loan payment problems.

\section{Outside Sources of Information}

The loan officers should be responsible for keeping abreast of current economic and financial developments as well as with news items involving clients or a client's industry. Loan officers should read local and national newspapers and periodicals such as the American Banker and the Wall Street Journal. At the local level, they should also review publications of the public records division of the city government. Such publications list all court proceedings and parties involved in foreclosures, civil suit judgments, divisional proceedings, mortgages and conveyances, assignments, etc. One bank officer indicated that this is probably the single most important publication used by loan review officers to determine legal activity in the credit environment.

\section{Renewed Loans Without Principal Reductions}

Loans are frequently renewed when the borrower cannot meet the current payment schedule, normally a result of cash flow problems. If there are no principal reductions within a reasonable period of time after the renewal, an inadequate cash flow may exist. The bank may wish to establish a policy regarding the allowed number of renewals without principal reduction before the loan is reviewed in detail. 
On a theoretical level, a renewed loan without principal reduction might not be considered as a problem loan. The impact of inflation on real interest rates may put the loan in a different light. For example, a loan renewed after a year of ten percent inflation has seen a real decrease in the principal amount owed because of the cheaper dollars needed to repay the loan. Presumably, the interest rate charged to the borrower will recoup this real principal reduction. Aside from this theoretical argument, lenders still expect a principal reduction of the loan on schedule.

\section{Other Signals of Potential Problems}

Other indicators commonly include miscellaneous and infrequently occurring items. A customer who fails to file current financial reports or other requested information with the bank could signal a problem. Significant devaluations of assets by the company from one statement to the next could also indicate problems. Banks should establish a monitoring system to track problem loans by industry or type of business. When a problem loan arises, such a system can provide an early warning concerning possible problems with other clients in the same industry or line of business. Finally, if the bank should know of personal financial problems of one or more principal parties of the business, the bank should make an effort to assure themselves that the problems do not extend to the bank loan.

\section{Problem Loan Identification - A Case Study}

To illustrate the application of some of the problem loan identification techniques, an actual case history provided by one of the banks interviewed is presented. Because of the confidential nature of the information, the name of the company and bank have been changed.

Gusher, Inc., is a corporation formed in 1979. The company drills for oil and gas throughout the Southwest region of the U.S. It was formed with a substantial amount of capital and was managed by proven, capable individuals. A loan for $\$ 5,620,000$ was made by Southwest bank for the purpose of purchasing two newly fabricated drilling rigs in January of 1981. Payments were made as agreed through September, 1982. At this point, Southwest's loan review department began receiving signals of a potential problem loan with Gusher.

Upon reviewing the bank's portfolio concentration in the first quarter of 1982, it was determined that the bank had an excessive number of "rig" loans, including the loan to Gusher, with respect to other types of loans. Appropriate notification was made to the other officers of the unhealthy concentration of loans. This was considered necessary because the oil and gas drilling industry continued to remain depressed during the first quarter of 1982 as a result of the high cost of drilling and the weakening price of and demand for petroleum products. An analysis of Gusher's 1981 year-end 
statements indicated that a potential decline in revenues was likely because of the economic conditions.

The past due report was used to determine that Gusher, Inc. was in trouble when it was late with its September, 1982 payment. In December, 1982, when it was reported that payments were over ninety days late, a special loan officer took the account and began a series of actions and negotiations. These are discussed in a later section. Southwest's system enabled it to address quickly the Gusher loan. When bank management detected a large number of oil and gas rig loans in its portfolio, it was able to limit its potential exposure in this area by declining any more loan requests.

\section{Managing Problem Loans}

The purpose of loan management is to prevent any unnecessary loss to the bank or unnecessary difficulties for the borrower. The management process should aid in a timely settlement and in proper financial treatment of the problem loan. The various aspects of loan management are discussed below.

\section{Accounting Status}

Banks typically account for loans on an accrual basis of accounting which allows an institution to claim interest income when it is earned (accrued) rather than when it is received. Once a loan has reached the point where it is placed in the hands of a special loan officer, for example when it is ninety days past due, a common policy of institutions is to place the loan on a nonaccrual basis until, according to bank policy, an established number of stable payments are received and sufficient collateral is obtained. In the Gusher loan situation, the loan was placed on a nonaccrual basis during March, 1983 when it was 180 days past due. All previously accrued interest was removed from the bank's income for 1983.

\section{Collateral Evaluation}

A collateral valuation is of utmost importance in determining how to manage a loan. All loans should be analyzed to determine their extent of collateralization. Such information is essential in the classification of loan risk and is also a necessary input to the proper accounting treatment of problem loans.

If the institution finds a problem loan to be fully collateralized, generally the loan will continue to be accounted for on a nonaccrual basis without a change in valuation. In a fully collateralized situation, the bank is secured and should receive the full amount of the loan through possible future repayment or sale of the collateral. On the other hand, if it is determined that the loan is undercollateralized, the FDIC requires the institution to reduce the outstanding principal to the amount of equity in the collateral and charge-off the rest, i.e. take a loss on the unsecured amount. 
Institutions do not like to foreclose or charge-off portions of loans, but if it is necessary as a last resort, a proper valuation of the collateral must be made. Gusher's two rigs were originally appraised at $\$ 7,500,000$ by the frabricator. The basis of the appraised value of a rig is a function of its revenue earning capacity. During 1982, day rates for drilling rigs plummeted to the point where the rigs were worth approximately $\$ 1,575,000$ (21\% of estimated original value) on a ninety day quick sale basis and approximately $\$ 3,541,500$ (47\% of estimated original value) on a reasonable market basis. As a result, Southwest Bank had to record a loss on the loan to comply with FDIC requirements. The amount of the loss will be discussed in the next section.

\section{Risk Classification}

Once an estimation of the value of the loan's collateral is determined, the institution should perform a classification of the risk on all loans. For example, an eight-tier rating system may be used - highest quality, very good quality, fair quality, OLEM (other loans exceptionally mentioned), substandard, doubtful, and loss. Loans receiving a risk classification above OLEM generally do not present a problem to the bank. This risk classification should be conducted periodically since such items as financial strength, valuation of collateral, etc, may change. If a loan receives a downgraded classification, particularly to one of the lower classifications, it should be carefully reviewed by the loan officer to determine if some action is necessary. Such a system can cut loan losses by providing an early signal of loans that may be approaching problems.

When a loan receives a rating of OLEM, it usually indicates that there are deficiencies in the borrower's financial situation, such as deteriorating financial ratios, cash shortages, etc. A substandard rating is given if there is little or no liquidity, cash flow for debt service is marginal, and payout through normal operations is doubtful. It is also substandard if debt repayment could depend in part on fixed asset liquidation or if loans are secured by acceptable collateral, where the collateral value is less than the amount owed. A loan classified as doubtful has all the weaknesses inherent in one classified substandard with the added provision that the weaknesses made collection or liquidation in full, on the basis of current existing facts, highly questionable and improbable. The possibility of loss is extremely high, but because of certain important and reasonably specific pending factors which may work to the advantage and strengthening of the loan, its classification as an estimated loss is deferred until its exact status may be determined. Loans classified as a loss are considered uncollectible and of such little value that their continuance as a loan of the bank is not warranted.

Classifying a loan frequently involves both the bank and its examiners. Each loan classification below OLEM lends itself to a percentage that must be taken as a loss - substandard (10 percent), doubtful (50 percent), loss (100 
percent). These loss amounts are only estimates and the FDIC will usually dictate the amounts which must be written off.

In the Gusher example, as the market for the drilling rigs and other petroleum products changed, the collateral valuations and risk classifications also fluctuated because the value is a function of its revenue earning capacity. After the last payment on the Gusher loan, the principal outstanding amounted to $\$ 5,518,000$. The collateral had a 90 -day quick sale value of $\$ 1,575,000$, and a reasonable market value of $\$ 3,541,000$.

Given these circumstances, the FDIC required Southwest Bank to take action on the Gusher loan. Essentially, the FDIC split the loan into three categories, a substandard amount, a doubtful amount, and a loss amount. The loss amount was determined to be the difference between the principal outstanding and the reasonable market value $(\$ 5,518,000-\$ 3,541,500=$ $\$ 1,976,500)$. The loss amount was charged against the bank's reserve for loan losses account (similar to Allowance for Bad Debts). The effect of this was to write off that portion of the loan. The substandard amount of the loan was defined by the FDIC to be the quick sale value of the collateral and they required Southwest to charge $10 \%$ of this amount against income and to credit the reserve account. In addition, the doubtful amount was defined as the difference between the reasonable market value and the quick sale value of the collateral $(\$ 3,541,500-\$ 1,575,000=\$ 1,996,500)$ and the FDIC required Southwest to charge $50 \%$ of this amount $(\$ 983,250)$ against income and to credit the reserve account. Thus in total, the FDIC required Southwest to immediately write off $\$ 1,976,500$, and to charge another $\$ 1,140,750$ $(\$ 157,500+\$ 983,250)$ against the loan as a potential loss.

\section{Workout of Problem Loans}

When the problem loan has been recognized, the bank should immediately try to do whatever is necessary to salvage the company and the loan. The bank should schedule the initial meeting with the client as soon as possible. This initial meeting should include (if possible) the CPA, attorneys and other principles. This meeting should be used to discuss the problems openly, review the financial position, and determine the relationship and status with other creditors. The latter is important, since the collapse of one client may, at times, have a substantial detrimental impact on other clients.

At the same time, the bank should perform an internal evaluation of the situation. The credit department should perform an analysis of the business including cash flow, and a ratio analysis. A proposed plan can be devised by the bank and presented to the client for discussion. When the customer and the bank agree on a plan, the bank should have the customer sign an informal agreement stipulating terms of the agreement.

\section{Administration of the Workout Plan}

After the bank and the customer agree on the workout plan, the bank 
should set up a file on the customer dealing solely with the workout plan. The new file is updated continuously with information regarding the plan. Where appropriate, the new terms of the loan are entered into the bank's computer system. The appropriate officer is notified of the status of the loan for monitoring just the same as the other loans of the bank. If the loan workout plan is not followed by the customer as agreed, another meeting should be scheduled to assess any new problems, and possible situations.

\section{Bankruptcy and Other Litigation}

In all dealings, the bank should stress that litigation is considered only as a last resort, and that the bank hopes the customer will consider bankruptcy only as a last resort. If indeed litigation becomes a probable consequence, the bank's attorney should be called in immediately to discuss the case. The attorney's recommendations are usually followed.

If bankruptcy is filed by the customer, the bank must arrange to attend the first meeting of creditors at the bankruptcy court. Before the meeting, the bank should provide information regarding the loan amounts and all pertinent information related to the loan to the court. After that meeting the court records are normally reviewed to determine the probable settlement for the bank. Once the probable amount is determined, the bank should adjust the value of the loan and record additional losses where necessary.

\section{Conclusion}

Although the bank is concerned with securing its position on the problem loan, it should also be concerned with the future of the borrower. The bank's goal should be to work with the troubled debtor to do whatever is feasible, within the constraint of minimizing loan losses, to help the debtor work out his financial difficulties. A foreclosure usually eliminates the opportunity for that borrower to continue to provide jobs, taxes, and goods for the community. Therefore, banks have a responsibility to work with the borrowers for a reasonable period of time in the hope that the borrower can survive. This assistance could be in the form of more favorable terms on the present loan or even additional loans to develop or modernize a product line to generate more revenues. The financial expertise of the loan officer should always be available to assist the borrower in the recovery process. In the Gusher case, the bank loan officer is continuing to work with the company to resolve the problem loan.

The procedures outlined above for the PLIM System should assist banks in the early identification of problem loans. This process can greatly assist the bank in minimizing loan losses. An early warning system can allow the bank to work with clients to overcome problems before they become serious. Proper management of problem loans will also reduce loan losses as well as provide a mechanism to make available the much needed assistance to the 
clients with financial difficulties. Thus any effective PLIM system should benefit the bank, the client and the local community.

\section{REFERENCES}

The materials for this article were obtained from personal interviews with commercial loan officers of four mid-sized banks in Baton Rouge, Louisiana. They have requested that their banks not be named in the article. 